\title{
Analysis of social well-being parameters in Russia (on the example of the remote Siberian region)
}

\author{
Bulatova Tatyana Alekseevna \\ Tomsk State Pedagogical University \\ Tomsk, Russia \\ bulatowa@mail.ru
}

\author{
Maklakova Taisiya Glebovna \\ National Research Tomsk Polytechnic University \\ Tomsk, Russia \\ mclakova.t@gmail.com
}

\author{
Romanchukov Sergey Viktorovich \\ National Research Tomsk Polytechnic University \\ Tomsk, Russia \\ inoy@vtomske.ru
}

The article studies dynamic of the Index of social feeling in Siberian region and its linking with modernization processes in Russia. The empirical base of the research was founded with the use of public opinion polls, which were provided in 2011, 2015. The research is complemented with the regional modernization map, which is based by calculating the modernization indexes following a method of the Modernization Research Center of China Academy. It was found that despite the crisis in 2015 the social feeling of the Russian population didn't change for the last five years. Regions with unbalanced modernization processes are still far from metropolises with the high level of social wellbeing. Tomsk region, as a separate Siberian region with an innovation status, has happier population than in whole Russia.

Key words: social welfare, social well-being, modernization, Siberian region.

\section{INTRODUCTION}

In the process of modernization we can consider the society as a moving force and the users of final result. In that regard, would be reasonable to study society in a view of factors, affecting on modernization potential: needs satisfaction, social interests, values, social activity, protection from the various dangers, social optimis $m$ and life satisfaction. All this factors effect on people's participation in modernization processes.

The purpose of the work is social wellbeing analysis of Siberian region in the context of Russian regional modernization. The research was provided in frame of the program "The sociocultural portrait of Russian Region", the measurement of modernization was proposed by the Modernization Research Center of China Academy, it was adapted for Russia [1].

\section{MODERNIZATION AS A FACTOR OF SOCIAL WELL-BEING}

Russia is characterized by big areas and territorial remoteness from the central region, Russian regions are differentiated by climate, culture and the history of foundation. There are big underpopulated territories (Eastern Siberia, North of Russia, Far East region) - frontiers, which are characterized by low level of social order, unequal access to resources, which provide social wellbeing [2]. There are also social and economic differences between regions: income level, the level of infrastructure development, the possibility of self-development and by-time.

On the basis of the regional modernization measurement differently modernized Russian territorial entities were distinguished (with the method of the Modernization Research Center of China Academy and information system from Volgograd "Institute of socio-economic development of the Russian Academy of Sciences.") [3]. Series of research studies showed general disbalance in modernization processes $[4,5,6$, 7,8]. It was found that the highest modernization level covers Moscow (Moscow region) and St. Petersburg, Nizhny Novgorod region, Samara region, Kaluga region, Arhangelsk region, Yaroslavl region, Sverdlovsk region, Perm Krai, Novosibirsk region, Tomsk region and Sakhalin region (see the annex RF regional modernization map 2012 , method: Modernization Research Center of China Academy; " Institute of socio-economic development of the Russian Academy of Sciences.", Volgograd).

The Purpose of this modernization is improvement of people's life and excess to social, economic and cultural benefits. I other words, the aim is the growth of social wellbeing, quality of life, the growth of the social feeling level. However, According to the research data, there was no connection between regional modernization and social feeling level. It means that modernized regions and regions with the high quality of life don't coincide (except Moscow). A study conducted by the Civil Society Development Fund in 2013 showed that the next regions were leaders in the social feeling rating: The Yamalo-Nenets autonomous district, The Tyumen region, The Belgorod region, The Republic of Tatarstan, The Republic of Bashkortostan, The Republic of Buryatia, The Kaluga region, The Kemerovo region, The Republic of Tuva and The Moscow city. The outsiders of this rating were: The Volgograd region, The Republic of Karelia, The Kursk region, 
The Kurgan region, The Kostroma region, The Arkhangelsk region and The Murmansk region.

There is a common point of view that satisfaction depends directly on society income level. More advanced studies say that satisfaction depends not so much on income level as social and economic stratification (Gini coefficient). [9] At the same time the science of subjective social feeling, which depends on other non-economic factors (protection, trust, religion, values, social evaluation and comparisons), aroused more interest. The studies confirmed that there are a lot of unhappy people in developed countries. The Easterlin paradox tells us, that reach countries are not better in the context of wellbeing, also people in countries with big income inequality can suffer from depression, which is not connected to income level $[10,11,12,13]$. The data shows: If the income inequality increases, the subjective social identity with the middle class decreases. Subjective wellbeing is also considered as directly dependent on gender equity and equality of rights [14]. The value of selffulfilment (for example an interesting and useful job) brings more happiness to people than big salary [11].

As we can see in general, social feeling is equal to social wellbeing and despite different calculation methods, it's not easy to define. $[15,16]$;

In the first figure we can see the social feeling rating: the leaders are marked striped, the outsiders are marked with one color. There is no negative correlation between life satisfaction and society stratification. We can notice, that regions with the high level of social feeling have higher Gini coefficient.

\section{The Gini coefficient in 2013}

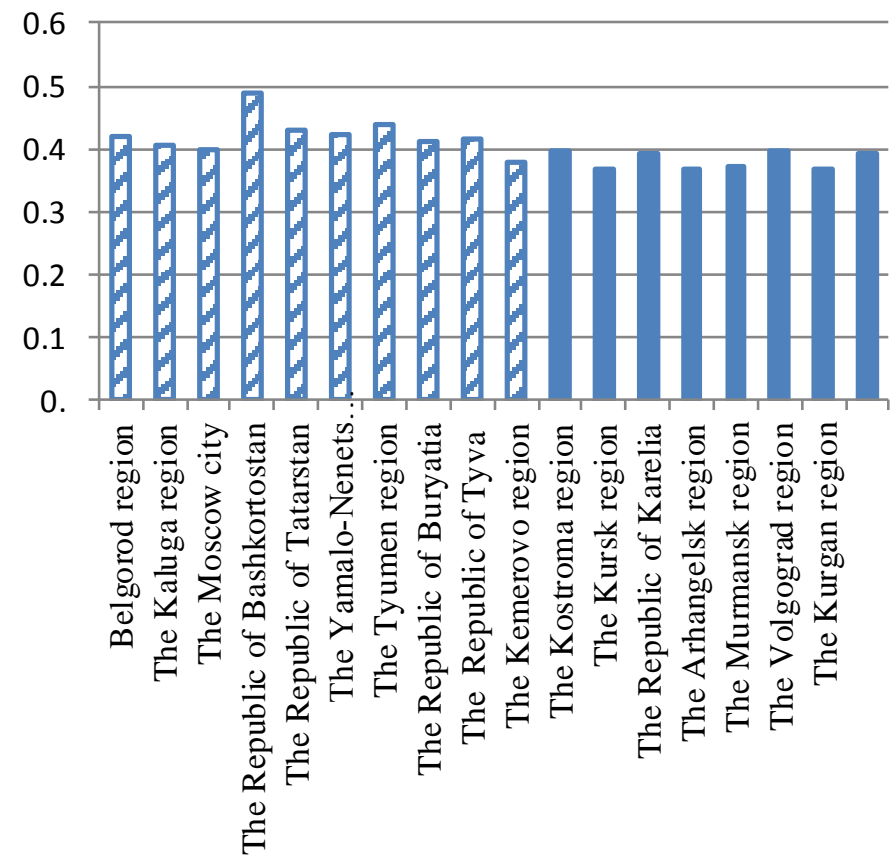

Fig. 1. Gini coefficient in Russian regions: the highest and the lowest points of the Index of social feeling.

\section{ANALYSISOF INDEX OF SOCIAL FEELING IN THEREGION AND RUSSIA}

The method of Index of social feeling (ISF) calculation is based on mass survey and includes three subjects: the middle value of social protection (PI), the life satisfaction level (SI) and the middle value of social optimism (OI). Weighting coefficients are equisignificant. The calculation formula is mentioned below.

$$
\mathrm{ISF}=(\mathrm{PI}+\mathrm{SI}+\mathrm{OI}): 3
$$

The lowest value for stable society is ISF $=0.5$ and higher. Values below the point 0.5 prove that there are some problems in society. The research presents the results, which were based on the mass survey of the Siberian region - Tomsk region. The first wave of study covered 750 people in 2011. The second 1000 people in 2015.

Processed by mathematical statistics method, Q-data outputted comparable parametrs, which were included in computation of Index of social feeling (table 1).

Protection Index from the various dangers consists of 10 indexes: enviromental threat, deprivation by age and sex,nationality, religious commitment, goverment's arbitrariness, arbitrariness of law enforcement authorities, persecution for political beliefs, poverty, desolation and neglect, criminality.

On the basis of the received responses, rating of hazard was made, it should be noted that such categories as «more unprotected» and «unprotected at all» were summarized.

The most pressing problems, from which the inhabitants of Tomsk and Tomsk region did not feel safe in 2011 were environmental threat and criminality $(61 \%$ and $60 \%$, respectively). In the third place in order of importance was the danger of goverment's arbitrariness (57\%). More than half of the residents pointed out the problem of poverty and the threat from arbitrariness of law enforcement authorities - equally $(51 \%)$.

According to a survey in 2015 in the first place were pointed out poverty threat and goverment's arbitrariness $(54.1 \%$ and $51.9 \%$, respectively), the third and the fourth place was taken by the problems of crime and environmental threats ( 49.8 and $45.7 \%$, respectively ). The danger from arbitrariness of law enforcement authorities have noted $40.5 \%$. Thus, the top of five problems (threats) in 2015, has retained its relevance in the region. However, it should be noted that, reduced their significance to the public environmental threat, the threat of crime and the arbitrariness of law enforcement authorities. The proportion of the population, who found it difficult to answer the question, was higher in 2015 than in 2011, which indicates the presence of hidden problems.

The concerns about the threat of desolation and abandonment, divided approximately equally in both panels of the research $(40 \%$ / $41 \%$, respectively, protected / unprotected in $2011 ; 36.3 \%$ / $38.3 \%$ - in 2015).

The research was conducted in Tomsk State Pedagogical University with financial support of RHSF (Russian Humanitarian Science Foundation), project 15-03-00366 "Social and cultural factors of the new regional modernization (according to the data of Tomsk region)". 
Table 1. Values of indexes (ISF) and subindexes

\begin{tabular}{|c|c|c|c|}
\hline \multirow{2}{*}{$\begin{array}{c}\text { Questions for evaluation subjective perception of } \\
\text { social feelings }\end{array}$} & \multirow{2}{*}{$\begin{array}{l}\text { Index/subindex } \\
\text { (title) }\end{array}$} & \multicolumn{2}{|c|}{$\begin{array}{l}\text { Values of indexes / } \\
\text { subindexes }\end{array}$} \\
\hline & & $(2011)$ & $(2015)$ \\
\hline $\begin{array}{l}\text { As of today, to what extent do you feel secure from } \\
\text { the various dangers? (10 dangers) }\end{array}$ & $\begin{array}{l}\text { PI - protection (subindex) } \\
\text { index }\end{array}$ & 0.57 & 0.62 \\
\hline $\begin{array}{c}\text { In common, to what extent are you satisfied with your } \\
\text { life ?(life satisfaction) }\end{array}$ & $\begin{array}{l}\text { SI - life satisfaction } \\
\text { (subindex) index }\end{array}$ & 0.71 & 0.70 \\
\hline $\begin{array}{l}\text { As of today, to what extent do you feel confident } \\
\text { about your future or you don't? (the degree of confidence } \\
\text { in the future) }\end{array}$ & $\begin{array}{l}\text { OII - optimism index (the } \\
\text { first subindex) }\end{array}$ & 0.67 & 0.68 \\
\hline $\begin{array}{l}\text { Have you and your family got a better life in } \\
\text { comparis on with last year or it has become worse? } \\
\text { (situational assessment of "today" being) }\end{array}$ & $\begin{array}{l}\text { OI } 2 \text { - optimism index (the } \\
\text { second subindex) }\end{array}$ & 0.64 & 0.56 \\
\hline \multirow[t]{3}{*}{$\begin{array}{l}\text { What do you think will you and your family have a } \\
\text { better or worse life in the coming year? (social } \\
\text { expectations) }\end{array}$} & $\begin{array}{l}\text { OI } 3 \text { - optimis } m \text { index (the } \\
\text { third subindex) }\end{array}$ & 0.67 & 0.66 \\
\hline & Total $O I$ & 0.67 & $\overline{0.63}$ \\
\hline & $\begin{array}{l}\text { ISF - Index of social } \\
\text { feelings }\end{array}$ & 0.65 & 0.65 \\
\hline
\end{tabular}

Note: $\mathrm{n} 1=750, \mathrm{n} 2=1000$; each coefficient (index/subindex) should be counted by 5 -ordinal scale from positive definite to negative definite answer.

Harassment's issue because of political beliefs, sex/age, religious commitment, nationality are not as prevalent in the region. The degree of social peace (protection) due to the lack of harassment according to the is sues in 2011/2015 is presented in the following order: age, sex (49\% / 58.4\%), according to religious commitment ( $47 \% / 70.6 \%)$, according to ethnicity (48\% / 73.8\%), political belifs $(46.3 \%$ in both panels of the study). In three of these dangers, the degree of protection on the perception by the inhabitants has increased. Reducing of concerns, on a number of these threats reflected on increasing degree of (subindex) protection ISF $(0.57 / 0.62)$.

In general, satisfaction with life expressed in the 2011/2015 years $-63 \% / 59 \%$, respectively, are not satisfied with life in the region to a greater or lesser extent, $23 \% / 24.4 \%$, respectively. As we can see, a sense of life satisfaction has declined among the residents of the region in 2015. It goes without saying that, the recession year had an impact on the number of components of the ISF. However on the whole, the life satisfaction index (subindex) has not changed in both study panels.

Due to our method, social feeling is also determined by social optimism, which consist of the degree of confidence in the future, situational optimism (self "today"), social expectations.

As a whole in 2015, reducing of social optimism index was on the subindex situational optimism -0.56 against 0.64 in
2011. In 2015, "life has become worse" and "nothing has changed" - said about $38 \%$ of the population for each question, respectively.

Social expectations were comparable in both panels of the study. Index (subindex) reflected a slight decline in its -0.66 against 0.67 in 2011. Subindex of confidence in the future found tends to increase in the future -0.68 against 0.67 in 2011.

According to our data, the latest wave of population surveys in the Tomsk region (2015 and data from similar studies in Russia (2105 panel $\mathrm{g}, \mathrm{n}=750$ ) as a whole show that the Index of social feeling in Russia (0.64) is close to the index as well as in the Tomsk region $(0,65)$.

As a whole, in the first place in Russia, on a number of fears and threats, as well as in the region, it takes the threat of poverty. Despite of the volatile socio-economic environment, amid the crisis, more than $40 \%$ of the respondents, both in the Tomsk region and in Russia, noted that more satisfied with their lives at the moment. About $17 \%$ of people in the region, considered that fully satisfied. Insufficient satisfied were about $22 \%$. It should be noted that, according to the nationwide survey, those who are not satisfied with their lives, it was almost 2 times more than in the Tomsk region, $4.2 \%$ against $2.3 \%$ of Russians Tomsk citizens.

Residents of the region feel optimistic about the future. 
Those who are quite confident in the future, among the residents of Tomsk and the region turned out to be $1 \%$ higher than among Russian citizens, and those who are prone to uncertainty on $6 \%$ less.

Assessing overlasted crisis year, some of the respondents acknowledged that they began to live a little better. Moreover, in the region such kind of responses twice as much as in Russia (17.2\% vs.8.4\%), and those who have become worse off by $7 \%$ less.

The residents of the Tomsk region were careful enough in their forecast, for the next year. About $20 \%$ of respondents could not give a decisive answer. Thus anyone who sees optimistic perspective in Tomsk was almost two times higher in comparison with the data on the Russian (13.8\% vs. $7.6 \%)$. Slightly higher was the share of those who is extremely pessimistic - 5.1\% of Tomsk citizens against $3.1 \%$ of Russians. The large majority felt that any changes will not follow.

Highly enough is estimated the region's population and level of wealth. $28.7 \%$ of the respondents have this level of income, which can sufficiently ensure his life. Those who have enough income to all, except the purchase of real estate for its own expense, in the Tomsk region in 2 times more than in Russia as a whole (18\% vs. $9 \%$ ).

In a survey of the population distant from the capital of the region largely relies on its efforts in addressing life issues. Rely fully only on themselves prefer to $64.2 \%$ of the respondents in the Tomsk region, at the same time in Russia it was only $49.2 \%$.

\section{CONCLUSION}

The status of subjective wellbeing in a remote Siberian region, measured by the Index of social feeling (ISF) in the dynamics of the two waves of the study shows the same index values, close to all-Russian 2015. In the region among the main dangers remain: environmental threat, poverty, goverment's arbitrariness, the arbitrariness of law enforcement authorities, criminality, with a change in the ranking over the years of research. Due to modernization process of economic and socio-cultural the region has preserved the level of wellbeing during the crisis in 2015 at the level of 2011. The majority of the population in the region do not foresee life's improving in the coming year, that reflects an understanding of the depth of the crisis and the duration of the modernization processes that can produce institutional and economic changes in the region and the country. Nevertheless, people have expressed optimis $m$ in the long-term perspective. The majority of the region's residents like living in Siberia.

One should think that overcoming the imbalance and deceleration of modernization processes in Russia and its regions, will inevitably lead to an increase in the social wellbeing of the population, including in remote Siberian regions. In this case, achieving the goal of modernization allows us to speak about the coincidence of the regions with a high component of modernization and regions characterized by high social wellbeing and feelings of the population.

\section{REFERENCES}

[1] N. Lapin, L. Belyaeva, The program and the standard toolkit "Sociocultural Portrait region of Russia" (Modification -2010). Moskow: Institute of Philosophy of the Russian Academy of Sciences, 2010. P. 135.

[2] R.-S. Foa, A. Nemirovskaya, How State Capacity Varies within Frontier States: A Multicountry Subnational Analysis. Governance. 2015. Available at https://publications.hse.ru/en/articles/168284318 (access date: 6.02.2016 ).

[3] M. Abramova, T. Bulatova, A. Rykun, K. Yuzhaninov, Problems of modernization and socio-cultural evolution of the Tomsk region (since 2000). Vestnik TSU Philosophy. Sociology. Political science Tomsk: TSU, 2012, №4 (20), pp. 175-196.

[4] N. Lapin, N. Kasavina, The imbalance of regional modernization processes, the Central zone of the Central Federal District. Sociological research. Moscow: Science, 2015, №3, pp. 29-36.

[5] E. Kogay, A. Kogay, Two trends of primary regional modernization, Central Black Earth region. Sociological research. Moscow: Science, 2015, №3, pp. 37-44.

[6] N. Dulina, N. Kargapolova, Between retarded growth and modernization of the region, South Federal District. Sociological research. Moscow: Science, 2015, №3, pp. 22-29.

[7] A. Nemirovskaya, The expected modernization of regions of the Far Eastern Federal District. Sociological research. Moscow: Science, 2015, №2, p. 41-48.

[8] G. Romashkina, Modernization processes in the regions of the Urals Federal District. Sociological research. Moscow: Science, 2015, №1, pp. 19-26.

[9] J. Delhey, G. Dragolov, Why Inequality Makes Europeans Less Happy: The Role of Distrust, Status Anxiety, and Perceived Conflict. European Sociological Review. UK: Oxford University, 2013, № 30(2), pp. 151-165.

[10] B. Stevensson, J. Wolfers, Economic Growth and Subjective Well-Being: Reassessing the Easterlin Paradox, 2008. Institute for the Study of Labor from http://ftp.iza.org/dp3654.pdf (access date: 8.12.2015).

[11] D. Skugor, E. Dingemans, Money Does Not Buy Much Happiness - But What Have Income Inequality, Modernization and Personal Values Got to Do with it? , 2012. Available at http://ssrn.com/abstract $=2057536$ (access date: 14.01.2016).

[12] R. Wilkinson, K.. Pickett, The Spirit Level. Why Equality is Better for Everyone. London: Penguin Press, 2010, P. 400. 
[13] I. Deurzen, E.Ingen, W. Oorschot, Income Inequality and Depression: The Role of Social Comparisons and Coping Resources European Sociological Review. UK: Oxford University, 2015, №31 (4), pp. 477- 489.

[14] A. Aassve, L. Mencarini M. Sironi, Institutional Change, Happiness, and Fertility. European Sociological Review. UK: Oxford University, 2015, № 31 (6), pp. 749-765.

[15] A. Campbell, The sense of well-beling in America. NewYork: McGraw-Hill Book Company, 1981, P. 263.

[16] E. Golovakha,N. Panina, A. Gorbachik, The measurement of social feelings: ISF test. Sociology, 1998, №10, pp. 45-72. 
